\section{シュードモナス属細菌によるアユの細菌性 出血性腹水病}

若林久嗣*1 ・沢田健蔵*2 $・$ 二宮浩司*3 西森栄太苂

(*1 東京大学大学院農学生命科学研究科, $* 2$ 徳島県試験場, *3 滋賀県水産試験場)

(1996 年 8 月 1 日受付)

\section{Bacterial Hemorrhagic Ascites of Ayu Caused by Pseudomonas sp.}

\author{
Hisatsugu Wakabayashi*1, Kenzo Sawada*2, \\ Kouji Ninomiya*3 and Eita Nishimori*1 \\ ${ }^{* 1}$ Graduate School of Agricultural and Life Sciences, \\ University of Tokyo, Bunkyo-ku, Tokyo 113, Japan \\ *2 Tokushima Prefectural Fisheries Experimental Station, \\ Hiwasa, Tokushima 779-23, Japan \\ ${ }^{*}$ Shiga Prefectural Fisheries Experimental Station, \\ Hikone, Shiga 522, Japan
}

(Received August 1, 1996)

A new bacterial disease, causing mass mortalities among pond-cultured ayu (Plecoglossus altivelis) in Shiga and Tokushima prefectures, was studied. Bloody ascites appeared to be the most characteristic sign of the disease. The causative organism was similar to Pseudomonas putida, but it did not produce fluorescent pigment and reduced nitrate to nitrite. Most of the isolates showed the API 20NE profile number of 1-140-457. An antiserum against the causative organism did not react with Ps. putida ATCC$12633^{\mathrm{T}}$.

Key words: ayu, Plecoglossus altivelis, Pseudomonas, Ps. putida, bacterial hemorrhagic ascites

最近数年間のアユ (Plecoglossus altivelis) の疾病動向を アユ生産県の水産試験場などの診断記録でみるとシュー ドモナス属細菌の感染症が年々増加しており, 冷水病と 首位を争うまでになっている。そこで, 本病の特徴と原 因菌の性状を明らかにすることを目的として，1994〜 1995 年に滋賀, 徳島の両県で発生した疾例と分離菌株に ついて調查した。

発病状況と疾状：本病は, 種苗を養成池に入れてから 10 日以降に発生する場合が多く, また, 冷水病対策とし て，種苗を加温処理したり投薬したりした後に本病が発 生した例もあった。
主な外見症状として, 眼球の軽い出血, 肛門の拡張・ 出血のほか, 頭部や下顎の発赤・出血や鰓の軽い分血が 観察された。また, 解剖所見としては, 血液の混じった 腹水の眝溜, 腹腔壁や内茞の点状出血, 直腸部の内出血 などが観察された。とくに血液混じりの腹水の貯溜は殆 んど全ての病魚に観察され, 最あ特徴的な症状であった (Fig. 1)。

原因菌の分離培養：原因菌は病魚の腎臓などの内臓試 料をトリプトソーヤ培地などの普通培地の寒天平板に接 種し，20〜 $25^{\circ} \mathrm{C}$ で 24〜 48 時間培養することによって無 色の円形コロニーとして容易に分離されたほか, TY 培 地やサイトファーガ培地など冷水病菌用の分離培地に よっても分離された。多くの場合は純粋培養状に分離さ れたが, Cytophaga psychrophila や Aeromonas hydrophila が同時に分離された場合ああった。

形態：1994 年に滋賀県で病アユから分離された菌株 FPC940 とFPC941，および同年徳島県で病アユから分 離された菌株FPC951 とFPC952について観察した。供 試 4 菌株は, いずれも運動をするグラム陰性桿菌で, 鞭 毛染色により極毛が観察された。また，1株について電 顕観察したところ，複極毛であった (Fig. 2)。

生理学的性状：上記 4 菌株のトリプトソーヤ液体培地 (日水) における発育温度を $5^{\circ} \mathrm{C}$ 間隔で調べたところ, いずれの菌株む 24 時間培養では $15 \sim 30^{\circ} \mathrm{C}, 48$ 時間培養 では $10 \sim 30^{\circ} \mathrm{C}$ で, 発育が肉眼的に認められた。発育塩 分濃度をぺプトン (Difco) 水を基礎培地として食塩 $1 \%$ 間隔で調べたところ，いずれの菌株も 24 時間培養では

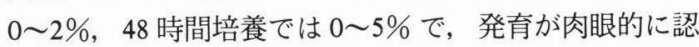
められた。また, 発育 $\mathrm{pH}$ をトリプトソーヤ液体培地の $\mathrm{pH}$ を $\mathrm{HCl}$ と $\mathrm{NaOH}$ で調整して調べたところ，24 時間 培養でも 48 時間培養でも $\mathrm{pH}$ 5 9 で, 発育が肉眼的に 認められた。

生化学的生状：常法に従って試験を行い， $25^{\circ} \mathrm{C}$ で 24 ないし 48 時間培養後に判定した。また, 非腸内細菌科細

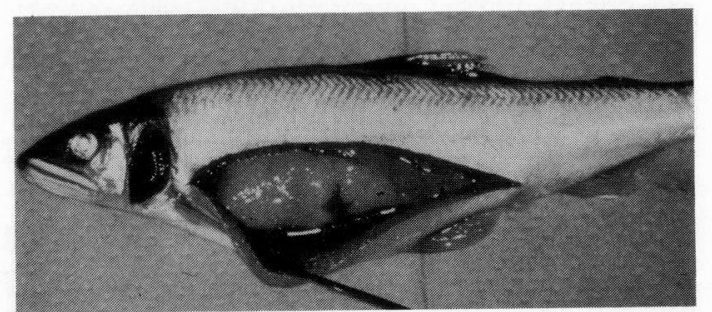

Fig. 1. Ayu infected with Pseudomonas sp., showing bloody ascites. 


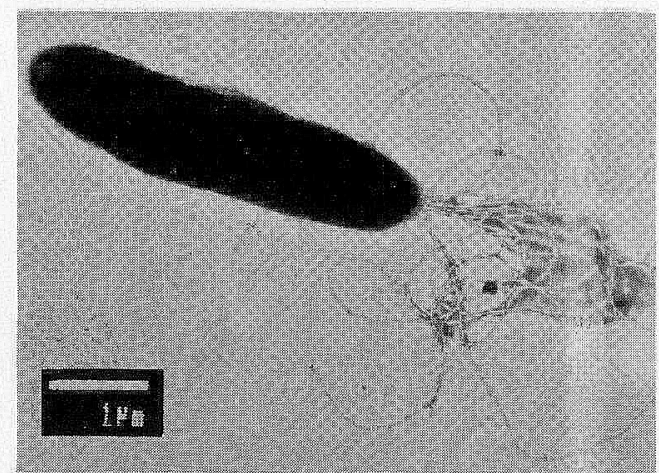

Fig. 2. Electron micrograph of Pseudomonas sp. strain FPC941.

菌同定キットAPI20NE システム(BioMerieux)を用い て簡易検査を行った。

供試 4 菌株の試験の結果は, チトクローム・オキシ ダーゼ産生 $(+)$, カタラーゼ産生 $(+), \mathrm{OF}$ 試験 $(\mathrm{O})$, ピオシアニン産生 $($ (一), フルオレッシン産生 $($ 一), ゼラ チン加水分解 $(一)$, 硝酸塩還元 $(+)$ であった。また, API20NEについては，上記 4 菌株のほかか，1995年に 德島県で病アユから分離された 13 菌株および 1995 年に 滋賀県で病アユから分離された 20 菌株について試験し たところ，上記 4 菌株と 1995 年徳島県株 13 菌株はす心 て同じ数值プロファイル 1-140-457を示したが, 滋賀県 株の数值プロフィルは，1-140-457が9菌株，1-142-457 が 5 菌株, 1-143-457, 1-144-457, 1-146-457, 1-140-455, 0-157-755, 2-674-305, がそれぞれ 1 菌株ずつであった。 （追記：1996 年1 6 月に滋賀県で分離された 11 菌株の 数值プロファイルはすべて 1-140-457であった）

G+C 含量: 菌株 FPC940 と FPC951 の DNA の G+ C含量を熱変性法で測定したところ, それぞれ $63.2 \%$ と $62.8 \%$ であった。

血清学的性状：菌株 FPC940 よ FPC951 それぞれのホ ルマリン不活化菌体に対する家兔抗血清を常法により作 製した。これら 2 つの抗血清は, 1994 年分離菌株の FPC 940, FPC941, FPC951, PFC952 のいずれに対しても同じ 凝集素価をしめしたが，Pseudomonas putida の標準菌株 ATCC12633 とは反応しなかっった1995 年に滋賀県で病 アユから分離された前記 20 菌株について凝集反応を試 しみたところ，API20NE の数值プロファイルが 0-157755 と2-264-305 でっっ 2つの菌株はいずれの抗血清 とも反応しなかっったが，その他の菌株はいずれの抗血清 とも反応した。

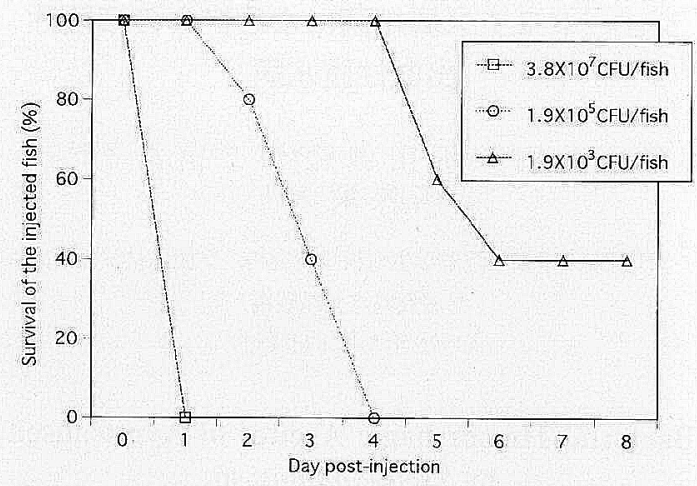

Fig. 3. Challenge of ayu weighing $10-20 \mathrm{~g}$ with Pseudomonas sp. by i.p. injection.

感染実験：(1)前記 1994 年分離菌株 4 株の病原性を調 ベた。备菌株について 3 尾ずつのアユ $(1.8 \sim 2.0 \mathrm{~g})$ を用 い，生理食塩水に䀣濁した供試菌株を約 $10^{4}$ ずつ腹腔内 注射し，水温約 $20^{\circ} \mathrm{C}$ の水槽に収容した。刘照区のアユ には生理食塩水を腹腔内注射した。どの菌株においても 2 日以内に全ての供試魚が死亡し，いずれの死亡魚から 6倛試菌株が再分離された。

(2)1995 年に滋賀県で分離された 1 菌株について, 菌濃 度を変えて感染実験を行った。生理食塩水に懸濁した菌 液を各濃度について 5 尾ずつのアュ $(10 \sim 20 \mathrm{~g})$ に腹腔 内注射し，水温約 $20^{\circ} \mathrm{C}$ の水槽に収容した。その結果，

Fig. 3 のように菌濃度に依存した死しがおこり，本病の 定型的な症状が再現され，供試菌株が再分離された。

考察：病魚から分離された菌株は，既知菌種のなかで はPS. putida にもっとも近い性状をもつが，蛍光色素を 産生せす，硝酸塩を還元するなどの点で，定型的な Ps. putida とは晎なるり。また，大部分の分離菌株は，簡易同 定システムAPI20NE の数値プロフィル 1-140-457を示 し, その他の分離菌株の数值プロフィルす2株 (0-157755, 2-647-305) 以外は僅かな違いである。なお, BioMerieux 社によれば, 数值プロファイル 1-140-457の既知 種に対する類似值は, Ps. putida, \% id=58.4, $T=0.71 ; P$ s. mendocina, \% $\mathrm{id}=32.6, T=0.50$ とされている。これらの ことから，本病は特定の細菌による未報告の流行病であ り，その原因菌は Ps. putida の新亜種あるいは Pseudomonas 属の新種と考察される。

\section{文献}

1) N. J. Palleroni (1984): In "Bergey's manual of systematic bacteriology, Vol. 1" (ed. by N. R. Krieg). Williams \& Wilkins, Baltimore/London, pp. 141-219. 